\title{
AKTIVITAS ANTIBAKTERI DARI BEBERAPA TINGKATAN MUTU TERASI UDANG REBON
}

\author{
Romadhon ${ }^{\star}$, Laras Rianingsih, Apri Dwi Anggo \\ Program Studi Teknologi Hasil Perikanan \\ Fakultas Perikanan dan Ilmu Kelautan, Universitas Diponegoro \\ Jalan. Prof. Soedarto, SH, Tembalang, Semarang, Jawa Tengah-50275, Telp/Fax. +6224 7474698 \\ Korespondensi: romi_thp@yahoo.co.id \\ Diterima: 19 Juli 2017/ Disetujui: 26 Maret 2018
}

Cara sitasi: Romadhon, Rianingsih L, Anggo AD. Aktivitas antibakteri dari beberapa tingkatan mutu terasi udang rebon. Jurnal Pengolahan Hasil Perikanan Indonesia. 21(1): 68-76.

\begin{abstract}
Abstrak
Terasi merupakan produk fermentasi ikan atau udang berbentuk pasta padat yang diolah secara tradisional. Bakteri asam laktat dapat diisolasi dari produk terasi dan menghasilkan senyawa antibakteri yaitu bakteriosin. Bakteriosin sebagai pengawet makanan memiliki kelebihan antara lain: dapat mengalami degradasi oleh enzim proteolitik dalam pencernaan manusia sehingga tidak membahayakan untuk kesehatan manusia. Penelitian ini bertujuan menentukan komposisi kimia dan aktivitas antibakteri bakteriosin asam laktat yang diisolasi dari bebrapa tingkatan mutu terasi rebon. Analisis menggunakan terasi grade 1, grade 2 , grade 3, yang ditentukan oleh perbandingan rebon dan bahan tambahan pada proses pembuatannya. Hasil isolasi bakteri asam laktat diperoleh 549 isolat sedangkan isolat BAL yang menghasilkan bakteriosin diperoleh 18 isolat. Bakteriosin dari BAL yang diisolasi dari terasi dapat menghambat ketiga jenis bakteri patogen dan pembusuk yaitu Eschericia coli, Vibrio parahaemiliticus, dan Staphylococcus aureus. Bakteriosin dari isolat BAL yang dapat menghambat bakteri patogen dan pembusuk yang terbaik yaitu terasi grade 1. Kualitas terasi terbaik pada grade 1 dengan kadar protein $42,78 \pm 1,28^{\mathrm{a}}$, lemak $5,33 \pm 0,53^{\mathrm{a}}$, asam glutamat. $40,50 \pm 0,06^{\mathrm{a}}$.
\end{abstract}

Kata kunci : antibakteri, bakteri asam laktat, bakteriosin, terasi, udang rebon

\section{Antibactery Activities from Some Quality Rate of Rebon Shrimp}

\begin{abstract}
Terasi is a fermented fish or shrimp product in the form of solid pasta traditionally processed. Lactic acid bacteria can be isolated from terasi products and produce antibacterial compounds ie bacteriocin. Bacteriocin as a food preservative has advantages such as: bacteriocin can be degraded by proteolytic enzymes in human digestion so as not to harm human health. This study aims to determine the chemical composition and antibacterial activity of lactic acid bacteriocin isolated from several levels of quality of shrimp paste rebon. The analysis used shrimp paste rebon grade 1 , grade 2 , grade 3 , which is determined by the ratio of rebon and auxiliary materials to the manufacturing process. Lactic acid bacteria isolation results obtained 549 isolates while isolates of BAL that produce bacteriocin obtained 18 isolates. Bacteriocin from BAL isolated from terasi can inhibit the three types of pathogenic and decaying bacteria Eschericia coli, Vibrio parahaemiliticus, and Staphylococcus aureus. Bacteriocin from BAL isolates that can inhibit the best pathogen and spoilage bacteria that is terasi grade 1 . The best quality of shrimp paste on grade 1 with protein content $42,78 \pm 1,28^{\mathrm{a}}$, lipid content $5,33 \pm 0,53^{\mathrm{a}}$, glutamic acid content $40,50 \pm 0,06^{\mathrm{a}}$.
\end{abstract}

Keywords : antibacterial, bacteriocin, lactic acid bacteria, shrimp paste 


\section{PENDAHULUAN}

Terasi adalah suatu jenis penyedap makanan berbentuk pasta, berbau khas hasil fermentasi udang, ikan, atau campuran keduanya dengan garam atau bahan tambahan lain. Negara-negara di Asia Selatan dan Tenggara hampir semua memiliki produk ini yaitu hentak, ngari, dan tungtap di India, bagoong di Filipina, terasi di Indonesia, belacan di Malaysia, ngapi di Myanmar, ka-pi di Thailand (Thapa 2002). Menurut Sharif et al. (2008) terasi merupakan produk awetan ikan-ikan kecil atau rebon yang telah diolah melalui proses pemeraman atau fermentasi, penggilingan atau penumbukan, dan penjemuran. Beberapa penelitian yang mengisolasi bakteri asam laktat dari terasi antara lain: isolasi bakteri asam laktat strain Staphylococcus piscifermentans produk udang terfermentasi (cincaluk) (Hajar 2013), isolasi bakteri asam laktat yang berpotensi sebagai probiotik berasal dari terasi udang (balacan) (Haitham 2017).

Bakteri asam laktat (BAL) adalah kelompok bakteri anaerob fakultatif gram positif yang mampu menghasilkan molekul antagonis dalam media pertumbuhannya yang bisa digunakan sebagai antimikroba dan pengawet. Sifat antagonis dari BAL yang aman dalam makanan fermentasi produk tradisional yang menjadikannya sangat bermanfaat sebagai biopreservatif yang bisa menggantikan atau mengurangi bahan kimia aditif (Arena et al. 2016).

Bakteri asam laktat secara alami dapat ditambahkan sebagai starter untuk memperpanjangan umur simpan fermentasi produk. Daya awet produk dapat terjadi karena penghambatan pertumbuhan bakteri pembusukan dan bakteri patogen makanan. Hal ini karena persaingan nutrisi dan adanya sifat senyawa bioaktif misalnya asam laktat, hidrogen peroksida, diasetil dan bakteriosin (Noordiana et al. 2013).

Molekul antagonis yang diproduksi oleh BAL adalah bakteriosin yang merupakan peptida antimikroba atau protein yang diproduksi oleh strain beragam spesies bakteri. Aktivitas antimikroba secara alami menghambat bakteri patogen yang dibawa makanan, serta bakteri pembusuk Noopur et al. (2010)
Bakteriosin merupakan senyawa protein yang memiliki efek bakterisida terhadap mikroorganisme lain. Bakteriosin dari BAL atau BAL yang menghasilkan bakteriosin secara umum dianggap aman untuk konsumsi manusia dan dapat diaplikasikan dalam pengawetan makanan. Penggunaan bakteriosin dalam industri makanan dapat membantu untuk mengurangi penambahan pengawet kimia sama misalnya mengurangi intensitas perlakuan panas, dan pada akhirnya akan menghasilkan makanan yang lebih awet secara alami dan lebih kaya akan sifatsifat organoleptik dan nutrisinya. Keawetan ini disebabkan BAL berkontribusi dalam menghambat pertumbuhan bakteri pembusuk dan patogen. Hambatan ini karena BAL dapat memproduksi beberapa metabolit misalnya asam organik (asam laktat dan asetat), hidrogen peroksida, diasetil dan bakteriosin (Gálvez et al. 2007).

Paradigma pengawetan pangan telah beralih untuk menghasilkan dan mengkonsumsi pangan yang lebih alami yaitu seminimal mungkin menggunakan bahan pengawet kimia. Hal ini menyebabkan perhatian bergeserke proses pengawetan secara alami di antaranya adalah pengembangan aplikasi bakteri asam laktat dan bakteriosin (Yu et al. 2012).

Penggunaan bakteriosin sebagai bahan pengawet makanan dapat mempertahankan sifat organoleptik dan kandungan nutrisi tidak hilang. Hal ini dapat menjamin keamanan makanan, kesegaran rasa, kesiapan untuk disajikan, dan penampakan dari produk. Fungsi bakteriosin jika ditambahkan pada makanan anatara lain sebagai bahan pengawet, zat additif atau bumbu perasa, starter bakteriogenik, bahan tambahan untuk melindungi kultur mikroba, bakteriosin yang diimobilisasi dapat digunakan sebagai bioaktif pengemasan bahan makanan (Galvez et al. 2007).

Beberapa bakteriosin dihasilkan dari bakteri asam laktat yang berasal dari produk-produk fermentasi, di antaranya Pediococcus pentosaceus yang diisolasi dari rusip menghasilkan bakteriosin yang bersifat sensitif terhadap enzim proteolitik yaitu proteinase- $\mathrm{K}$ dan papain. Bakteriosin tersebut stabil terhadap suhu tinggi dan $\mathrm{pH}$ 
2-8 serta menghasilkan aktivitas antibakteri yang tertinggi terhadap Staphylococcus aureus (Kusmawarti et al. 2014). Bakteri asam laktat diisolasi dari fermentasi ikan dan udang "Pha ak trey, pha ak kampus" (makanan tradisional dari Kamboja) menghasilkan bakteriosin yang dapat menghambat bakteri Listeria monocytogenes (Peng et al. 2017). Zona hambat yang mengindikasikan bahwa senyawa aktifnya masing-masing ialah asam organik dan bakteriosin dari bakteri asam laktat yang diisolasi dari bekasam. Zona hambat tertinggi dari supernatan dan endapan pada isolat $\mathrm{BP}(3)$ dan SK(5) masing-masing terhadap L. monocytogenes dan S. typhimurium. Zona hambat tertinggi dari supernatan pada isolat $\mathrm{BP}(20)$ dan $\mathrm{BI}(3)$ masing-masing terhadap S. typhimurium dan S. typhimurium dan E. coli. Sedangkan zona hambat tertinggi dari endapan pada isolat $\mathrm{BP}(20)$ dan $\mathrm{BI}(3)$ sama, yaitu terhadap E. coli. Desniar et al. (2011).

Berdasarkanadanyapenelitianbakteriosin yang dihasilkan dari bakteri asam laktat yang diisolasi dari terasi, maka penelitian tentang pengaruh aktivitas antibakteri daribakteriosin yang diiisolasi dari kualitas terasi yang berbeda-beda perlu dilakukan. Penelitian ini bertujuan menentukan komposisi kimia dari produk terasi rebon dan aktivitas antibakteri bakteriosin asam laktat yang diisolasi dari bebrapa tingkatan mutu terasi rebon.

\section{BAHAN DAN METODE Bahan dan Alat}

Bahan yang digunakan dalam penelitian ini adalah terasi yang memiliki kualitas berbeda-beda. Terasi grade 1 berasal dari rebon yang ditangkap dari tambak. Terasi grade 2 berasal dari 50\% rebon tambak dan $50 \%$ rebon dari laut. Terasi grade 3 berasal dari rebon laut. Terasi ini diperoleh dari unit pengolahan terasi di Kabupaten Pati. Bakteri yang digunakan untuk pengujian aktivitas antimikroba meliputi Escherichia coli (gram negatif), Staphylococcus aureus (gram positif dan bakteri anaerobik), Vibrio parahaemolyticus (gram negatif). Media de Man Rogosa Sharpe Agar (MRS) (Merck), Nutrient broth (NB) (Oxoid), Nutrient Agar (NA) (Oxoid). Bahan kimia yang digunakan $\mathrm{CaCO}_{3}$ (Merck), $\mathrm{H}_{2} \mathrm{SO}_{4}$ (Merck), $\mathrm{H}_{3} \mathrm{BO}_{3}$,
$\mathrm{NaOH}$ (Merck), 1 N HCL (Merck).

Alat yang akan digunakan dalam penelitian ini adalah autoclaf (All America), timbangan analitik (Libror AEG -220), bio freezer $-80^{\circ} \mathrm{C}$ (Forma Scientific), incubator $37^{\circ} \mathrm{C}$ (Leec), oven (Memmert), mikropipet (Eppendorf), waterbath (Haake D8), stirrer plate (nuova II), ultrasentrifuse suhu $4^{\circ} \mathrm{C}$ (Sigma Sartorius 3-30K), spektrofotometer (Shimadzu UV-Vis 6A), mikroskop fase kontras (Nikon), mikrosentrifuse (Beckman Microfuge 11), pH meter 691 (Metrohm).

\section{Metode Penelitian}

Penelitian ini dilakukan dalam empat tahapan yaitu 1) analisis kualitas terasi; 2) isolasi bakteri asam laktat pada terasi; 3) seleksi bakteri asam laktat penyebab bakteriosin; 4) skreening bakteriosin terhadap bakteri indikator.

\section{Analisis kualitas terasi}

Analisis Komposisi Kimia

Uji kadar air menggunakan metode Moisture Analyzer MB45 Ohaus (AOAC 2007). Sampel sebanyak 2 g dimasukkan ke dalam cawan, kemudian dimasukkan ke alat moisture analyzer, serta ditekan "start" untuk memulai. Nilai kadar air akan tertera pada layar, jika proses sudah selesai tekan tombol "stop".

Uji kadar protein menggunakan metode Mikro-Kjeldhal (AOAC 2005). Sampel kering sebanyak 5 gram ditempatkan dalam labu Kjeldahl $100 \mathrm{~mL}$ dan ditambahkan 0,25 gram selenium dan $3 \mathrm{~mL} \mathrm{H}_{2} \mathrm{SO}_{4}$ pekat, selanjutnya dilakukan destruksi (pemanasan dalam keadaan mendidih) selama 1 jam sampai larutan jernih. Sampel yang telah dingin ditambahkan $50 \mathrm{~mL}$ akuades dan $20 \mathrm{~mL} \mathrm{NaOH}$ $40 \%$ lalu didestilasi. Hasil destilasi ditampung dalam labu erlenmeyer yang berisi campuran $10 \mathrm{~mL} \mathrm{H}_{3} \mathrm{BO}_{3} 2 \%$ dan 2 tetes indikator Brom Cresol Green-Methyl Red berwarna merah muda. Volume hasil tampungan (destilat) menjadi $10 \mathrm{~mL}$ dan berwarna hijau kebiruan maka destilasi dihentikan, kemudian destilat dititrasi dengan $\mathrm{HCl} 0,1 \mathrm{~N}$ sampai berwarna merah muda. Perlakuan yang sama dilakukan juga terhadap blanko. Kadar protein dihitung dengan rumus: 
Uji kadar lemak dengan menggunakan metode soklet (AOAC 2005). Sampel Kadar nitrogen $(\%)=\frac{(\mathrm{B}-\mathrm{A}) \times \mathrm{Cx} 14,007 \times 100 \%}{\mathrm{D}}$ Kadar protein $(\%)=$ kadar nitrogen $(\%) \times \mathrm{FK}$ Keterangan:

A : volume $\mathrm{HCl}$ untuk titrasi blanko

B : volume $\mathrm{HCl}$ untuk titasi sampel (ml)

$\mathrm{C}$ : normalitas $\mathrm{HCl}$ yang digunakan $(\mathrm{N})$

$\mathrm{D}$ : bobot sampel (mg)

FK : faktor konversi $(6,25$ untuk produk perikanan)

seberat 2 gram (W1) disebar di atas kapas yang beralaskan kertas saring dan digulung membentuk thimble. Sampel yang telah dibungkus dimasukkan ke dalam labu lemak yang sudah ditimbang berat tetapnya (W2) dan disambungkan dengan tabung soklet. Selongsong lemak dimasukkan ke dalam ruang ekstraktor tabung sokletdan disiram dengan pelarut lemak (n-heksana). Kemudian dilakukan refluks selama 6 jam. Pelarut lemak yang ada dalam labu lemak didestilasi hingga semua pelarut lemak menguap. Pelarut akan tertampung di ruang ekstraktor pada saat destilasi. Pelarut dikeluarkan sehingga tidak kembali ke dalam labu lemak, selanjutnya labu lemak dikeringkan dalam oven pada suhu $105^{\circ} \mathrm{C}$, setelah itu labu dimasukkan dalam desikator sampai beratnya konstan (W3). Kadar lemak ditentukan dengan rumus:

$$
\text { Kadar lemak }(\%)=\frac{\mathrm{W} 3-\mathrm{W} 2}{\mathrm{~W} 1} \times 100 \%
$$

Uji kadar abu mengacu pada (BSN 2009). Cawan kosong dipanaskan dalam tanur selama 30 menit sampai suhu $525 \pm 25^{\circ} \mathrm{C}$ kemudian dioven pada suhu $105 \pm 3^{\circ} \mathrm{C}$ selama 1 jam kemudian didinginkan didesikator sampai mencapai suhu kamar. Cawan kosong ditimbang (A). Sampel yang telah diketahui kadar airnya ditimbang (B), kemudian dimasukan ke tanur dan diabukan pada suhu $525 \pm 25^{\circ} \mathrm{C}$ selama $3 \mathrm{jam}$. Sampel dioven pada suhu $105 \pm 3^{\circ} \mathrm{C}$ selama $1 \mathrm{jam}$. Cawan berisi abu didinginkan di desikator sampai mencapai suhu kamar. Cawan berisi abu ditimbang sampai diperoleh berat tetap dengan beda berat penimbangan maksimal 0,2 mg.

\section{Uji Asam Glutamat}

Pengujian asam glutamat untuk mengetahui kandungan asam glutamat pada kualitas trasi yang dihasilkan mengacu pada BSN (1995). Sampel sebanyak 0,1-0,2 g dimasukkan ke dalam labu Kjeldahl dan ditambahkan $5 \mathrm{~g}$ campuran selen dan $20 \mathrm{~mL}$ asam sulfat pekat teknis kemudian dipanaskan di dalam ruang asam, mula-mula dengan nyala kecil sambil digoyang-goyangkan. Api dibesarkan selama 5-10 menit dan terus dipanaskan hingga warna cairan menjadi hijau.Sampel dingin diencerkan dengan $50 \mathrm{~mL}$ air dan dipindahkan kedalam labu didih 250 mL. Sampel kemudian ditambahkan $40 \mathrm{~mL}$ $\mathrm{NaOH} 40 \%$ dan disambungkan dengan alat penyuling selama 50 menit dan hasil sulingan yang terdapat ditampung dengan $\mathrm{H}_{3} \mathrm{BO}_{3} 2 \%$ kemudian di titar dengan $\mathrm{HCI} 0,1 \mathrm{~N}$.

\section{Isolasi bakteri asam laktat}

Bakteri asam laktat diisolasi dari terasi menggunakan teknik pengenceran taburan (dilution series-pour-plate) pada media MRS. Sampel ditimbang $1 \mathrm{~g}$, dihancurkan dan disuspensikan ke dalam air steril Cai (1999). Pengenceran menggunakan air laut dan akuades steril dengan perbandingan $70 \%$ dan $30 \%$. Sampel diencerkan $10^{-1}, 10^{-2}, 10^{-3}$ dan $10^{-4}$. Sampel diisolasi dengan teknik pour plate dalam $20 \mathrm{~mL}$ MRS agar yang sudah ditambah dengan $\mathrm{CaCO}_{3} 1 \%$ dan $\mathrm{Na}$ azide $0,01 \%$. Sampel diinkubasi secara aerob 24-48 jam pada suhu $37^{\circ} \mathrm{C}$. Isolat yang menghasilkan asam ditandai terbentuknya zona jernih. Isolat dimurnikan dengan cara distrike ke media agar 3 sampai 4 untuk memperoleh isolat murni. Isolat murni disimpan dalam tabung ependop yang ditambah dengan skim milk dan gliserol 1:1 kemudian disimpan ke dalam freezer suhu $-80^{\circ} \mathrm{C}$ untuk persiapan tahap selanjutnya.

\section{Seleksi bakteri asam laktat penghasil bakteriosin}

Metode yang digunakan dalam pengujian ini yaitu well difusion. Persiapan yang dilakukan dengan menumbuhkan isolat bakteri asam laktat ke dalam MRSB pada suhu $37^{\circ} \mathrm{C}, 24 \mathrm{jam}$. Isolat pada tabung erlenmayer berumur 24 jam disentrifuse $13.000 \mathrm{rpm}$ selama 15 menit dan dipisahkan supernatan 
dan peletnya. Supernatan yang diperoleh dipanaskan pada suhu $80^{\circ} \mathrm{C}$ selama 5 menit yang bertujuan untuk mematikan sel dan menonaktifkan enzim proteolitik. Supernatan yang bebas dari sel di netralkan pHnya 6,5-7 dengan menggunakan $\mathrm{NaOH} 1 \mathrm{~N}$, tujuannya yaitu aktivitas daya hambat berasal dari bakteriosin. Media MRS agar padat dituangkan ke dalam cawan petri sebanyak $5 \mathrm{~mL}$. Media MRS setelah memadat kita pasang ring diameter $7 \mathrm{~mm}$ sebagai sumuran di atas medium padat. Bakteri indikator Pediococcus accidilactici LB 42 (umur 24 jam) dimasukkan ke dalam MRS lunak $(0,77 \%$ agar $) \quad 50 \mu \mathrm{L}$, setelah tercampur dimasukan $15 \mathrm{~mL}$ agar lunak kedalam agar padat yang terdapat sumuran. Sumuran yang telah memadat diambil dengan pinset steril sehingga terbentuk sumur pada media MRS lunak, kemudian dimasukkan supernatan netral kedalam sumur sebesar $50 \mu \mathrm{L}$. Supernatan dari Pediococcus acidilactici F11 (umur 24 jam) digunakan sebagai kontrol positif. Sampel dimasukan ke dalam sumuran dan simpan pada suhu $5^{\circ} \mathrm{C}$ selama 1 jam yang bertujuan memberi kesempatan agar bakteriosin berdifusi ke dalam agar sebelum bakteri indikator tumbuh, kemudian di inkubasi pada suhu $37^{\circ} \mathrm{C}$ selama $24 \mathrm{jam}$. Isolat yang menghasilkan bakteriosin akan nampak zona jernih.

\section{Skrining bakteriosin sebagai antibakteri}

Isolat bakteri asam laktat dimasukkan ke dalam MRSB pada suhu $37^{\circ} \mathrm{C}, 24 \mathrm{jam}$. Isolat yang berumur 24 jam disentrifuse $13.000 \mathrm{rpm}$ selama 15 menit dan dipisahkan supernatan dan peletnya. Supernatan yang diperoleh dipanaskan pada suhu $80^{\circ} \mathrm{C}$ selama 5 menit yang bertujuan untuk mematikan sel dan menonaktifkan enzim proteolitik. Supernatan yang bebas dari sel di netralkan pHnya 6,5-7 dengan menggunakan $\mathrm{NaOH} 1 \mathrm{~N}$. Metode yang dilakukan dengan menggunakan paper disk. Bakteri yang digunakan untuk pengujian aktivitas antimikroba meliputi E. coli (gram negatif), S. aureus (gram positif dan bakteri anaerobik), V. parahaemolyticus (gram negatif).

\section{Analisis Data}

Rancangan percobaan yang digunakan pada penelitian ini adalah rancangan faktorial untuk menganalisis pengaruh konsentrasi bakteriosin (15\%, 25\%) terhadap mutu produk perikanan dengan penyimpanan selama 9 hari. Pengamatan dilakukan selama 3 hari sekali $(0,3,6,9$ hari). Pengujian normalitas dan homogenitas dilakukan terlebih dahulu sebelum analisis ANOVA, agar dapat diketahui sifat data sehingga dapat dilakukan sidik ragam atau tidak. Metode analisis yang digunakan adalah sidik ragam ANOVA dengan uji lanjut untuk menentukan nilai yang berpengaruh maupun yang tidak dengan Uji BNJ (Beda Nyata Jujur).

\section{HASIL DAN PEMBAHASAN Komposisi Kimia}

Hasil analisis komposisi kimia menunjukkan terasi grade 1 memiliki kandungan protein lemak, air, dan abu lebih tinggi darai grade 2 dan 3, sedangkan kadar karbohidrat paling rendah (Tabel 1). Hal ini disebabkan karena rebon tambak memiliki kandungan protein lebih tinggi jika dibandingkan dengan protein rebon yang dari laut. Rebon dari tambak memperoleh makanan dari sisa-sisa pakan udang yang banyak mengandung protein, jika dibandingkan dengan rebon laut kandungan protein terasi dari rebon tambak memiliki protein lebih besar. Andriyani et al. (2012) melaporkan bahwa kadar protein udang rebon air laut yang dibuat oleh pengolah di desa Belo Laut kecamatan Bangka Belitung yaitu $35,86 \%$ dan 39,90\%. Romawati et al. (2013) menyatakan terasi ikan teri dengan perlakuan konsentrasi garam yang berbeda mempunyai kadar air $33,7 \%$ sampai $34,56 \%$. Terasi yang mempunyai kadar air tertinggi adalah terasi dengan konsentrasi garam 8,5\% yaitu $34,56 \%$.

\section{Kandungan Asam Glutamat}

Hasil analisis kadar asam glutamat terasi dapat dilihat pada Tabel 1. Berdasarkan uji statistik diperoleh hasil adanya perbedaan nyata $(\mathrm{P}<0,05)$. Kualitas terasi yang digunakan semakin rendah maka dihasilkan kadar asam glutamat semakin rendah. Jika dibandingkan 
Tabel 1 Komposisi kimia terasi udang

(Table 1 Chemical composition rebon shrimp)

\begin{tabular}{ccccccc}
\hline $\begin{array}{c}\text { Quality } \\
\text { of shrimp } \\
\text { paste }\end{array}$ & $\begin{array}{c}\text { Protein } \\
\text { content (\%) }\end{array}$ & $\begin{array}{c}\text { Lipid } \\
\text { content } \\
(\%)\end{array}$ & $\begin{array}{c}\text { Moisture } \\
\text { content (\%) }\end{array}$ & $\begin{array}{c}\text { Ash content } \\
(\%)\end{array}$ & $\begin{array}{c}\text { Carbohydrate } \\
\text { content (\%) }\end{array}$ & $\begin{array}{c}\text { Glutamic } \\
\text { acid (\%) }\end{array}$ \\
\hline Grade 1 & $42.78 \pm 1.28^{\mathrm{a}}$ & $5.33 \pm 0.53^{\mathrm{a}}$ & $27.85 \pm 1.54^{\mathrm{a}}$ & $29.48 \pm 0.39^{\mathrm{a}}$ & $14.78 \pm 0.60^{\mathrm{a}}$ & $40.50 \pm 0.06^{\mathrm{a}}$ \\
& & & & & & \\
Grade 2 & $34.29 \pm 0.92^{\mathrm{b}}$ & $3.55 \pm 0.60^{\mathrm{b}}$ & $23.66 \pm 0.41^{\mathrm{b}}$ & $41.40 \pm 0.45^{\mathrm{b}}$ & $19.08 \pm 0.29^{\mathrm{b}}$ & $22.47 \pm 0.12^{\mathrm{b}}$ \\
& & & & & & \\
Grade 3 & $39.31 \pm 0.40^{\mathrm{c}}$ & $2.18 \pm 0.55^{\mathrm{c}}$ & $21.98 \pm 0.81^{\mathrm{c}}$ & $45.51 \pm 1.37^{\mathrm{c}}$ & $15.97 \pm 0.80^{\mathrm{c}}$ & $19.82 \pm 0.12^{\mathrm{c}}$ \\
\hline
\end{tabular}

ketiga grade terasi tersebut maka terasi grade 1 memiliki kandungan asam glutamat paling besar, hal ini disebabkan kandungan protein terasi grade 1 paling besar sehingga asam glutamat yang merupakan salah satu komponen dari protein memiliki nilai yang cukup besar. Pembentukan asam glutamat pada ketiga produk terasi dengan bahan baku rebon yang berbeda dihasilkan melalui proses fermentasi. Proses fermentasi terasi tersebut terjadi proses pemecahan protein menjadi asam-asam amino salah satunya yaitu asam glutamat. Hajep dan Jinap (2012) menyatakan dalam proses fermentasi dihasilkan asam glutamat yang tinggi, asam-sam amino dan nukleotida yang berkontribusi dalam pembentukan rasa umami dari produk.

\section{Isolat Bakteri Asam Laktat pada Produk Terasi}

Isolat bakteri asam laktat terasi grade 1 (277 isolat) lebih banyak dibandingkan dengan terasi grade 2 (165 isolat) dan grade 3 (107 isolat). Hal ini disebabkan terasi grade 1 dibuat dengan rebon dari tambak. Daerah tambak banyak terdapat sisa-sisa makanan yang mengandung bakteri probiotik dari pakan udang tambak sehingga bakteri probiotik yang umumnya berasal dari bakteri asam laktat banyak terdapat pada usus udang rebon. Oshea et al. (2012) menyatakan mikroba usus telah diidentifikasi sebagai sumber yang kaya berpotensi probiotik bakteri yang menghasilkan antimikroba dan khususnya bakteriosin sebagai antibakteri patogen. Isolat-isolat tersebut merupakan isolat bakteri asam laktat yang merupakan hasil pemurnian, namun perlu dilakukan seleksi untuk melihat isolat-isolat bakteri asam laktat tersebut menghasilkan bakteriosin atau tidak.

\section{Seleksi Isolat Bakteri Asam Laktat Penghasil Bakteriosin}

Proses seleksi isolat bakteri asam laktat terhadap bakteriosin menggunakan bakteri indikator yaitu P. acidilactici LB 42. Bakteri indikator ini merupakan bakteri yang memiliki sensitifitas tinggi terhadap bakteriosin dibandingkan bakteri jenis lain. Selain itu memiliki sifat resistensi tinggi terhadap asam sehingga penghambatan pertumbuhan bakteri indikator yang terjadi benar-benar disebabkan oleh bakteriosin bukan asam. Bakteri kontrol positif menggunakan $P$. acidilactici F11. Bakteri kontrol positif merupakan bakteri yang menghasilkan bakteriosin. Hasil seleksi isolat bakteri asam laktat yang menghasilkan bakteriosin pada produk terasi sebanyak 18 isolat dari terasi grade 2 sebanyak 3 isolat, dan grade 3 sebanyak 7 isolat. Diameter zona hambat hasil skrining dengan bakteri P.acidilactici LB 42 yaitu terasi grade 1 sebesar $1,5 \mathrm{~mm}$, terasi grade 2 dihasilkan diameter zona hambat sebesar $2,8 \mathrm{~mm}$, dan terasi grade 3 menghasilkan zona hambat sebesar 1,85 
$\mathrm{mm}$. Jika dibandingkan dari tiap grade terasi, isolat BAL yang menghasilkan zona hambat paling besar yaitu pada isolat BAL yang dihasilkan pada terasi grade 2 yaitu sebesar $2,8 \mathrm{~mm}$. Hal ini disebabkan setiap BAL belum tentu menghasilkan bakteriosin karena bakteriosin merupakan metabolit sekunder yaitu dihasilkan pada kondisi tertentu. Terasi grade 2 menghasilkan zona jernih paling besar karena terasi diproduksi dari rebon dari tambak dan dari laut. Rebon dari laut ini kemungkinan mengandung isolat BAL yang menghasilkan bakteriosin karena kehidupan di laut lebih ektrim dibanding di tambak.

\section{Uji Skrining Bakteriosin sebagai antibakteri Eschericia coli}

Isolat BAL yang menghasilkan zona jernih pada uji skrining terhadap bakteri E. coli pada Tabel 2. Terasi grade 1 jika dibandingkan antara grade 2 dan 3 memeiliki diameter zona hambat terbesar yaitu 2,54 mm (Gambar 1). Hal ini disebabkan pada terasi grade 1 diproduksi dari rebon tambak dibandingkan dengan rebon laut. Hal ini dimungkinkan karena ditambak banyak pakan probiotik yang dikonsumsi oleh rebon tambak. Kandungan rebon tambak memiliki nutrisi baik yang dibutuhkan oleh pertumbuhan BAL pada proses fermentasi. Hal ini mendukung tumbuhnya isolat BAL yang menghasilkan bakteriosin yang mampu menghambat bakteri E.coli. Bakteriosin dapat menghambat pertumbuhan Eschericia coli karena kemampuan melisiskan sel dari bakteri patogen. Bakteriosin merupakan senyawa protein yang memiliki sifat bakterisidal terhadap bakteri patogen Gram positif dan negatif dengan spektrum yang luas terhadap bakteri target yang mempunyai sifat pengikatan spesifik (specific binding site) Nurhajati et al. (2012)

\section{Vibrio parahaemolitycus}

Isolat BAL yang menghasilkan zona jernih pada uji skrining terhadap bakteri Vibrio parahaemolitycus pada Tabel 2. Terasi grade 1 jika dibandingkan antara grade 1, 2, dan 3 memiliki zona hambat terbesar yaitu $2,10 \mathrm{~mm}$ (Gambar 1). Hal ini disebabkan BAL yang di isolasi dari terasi grade1 memiliki kemampuan menghambat bakteri Vibrio parahaemolitycus. Kemampuan bakteriosin dapat menghambat Vibrio parahaemolitycus karena bakteriosin mampu melubangi membran sitoplasma. Drider et al. (2006) menyatakan bahwa kerusakan yang terjadi akibat pembentukan lubang pada membran sitoplasma ditunjukkan oleh adanya materi dalam sitoplasma yang keluar dan masuknya materi yang ada dilingkungan sekitarnya. Kebocoran ini berdampak pada penurunan gradient $\mathrm{pH}$ seluler. Pengaruh pembentukan lubang sitoplasma secara umum sebagai dampak adanya bakteriosin, menyebabkan terjadinya perubahan gradien potensial membran $(\Delta \mathrm{P})$ dan pelepasan melekul intraseluler maupun masuknya substansi ekstraseluler (lingkungan). Efeknya menyebabkan pertumbuhan sel terhambat dan menghasilkan proses kematian pada sel yang sensitif terhadap bakteriosin.

\section{Staphylococcus aureus}

Isolat BAL yang menghasilkan zona jernih pada uji skrining terhadap bakteri Staphylococcus aureus disajikan pada Tabel 2. Terasi grade 1 jika dibandingkan antara grade 1, 2 dan 3 memiliki zona jernih paling yang paling besar (Gambar 1). Hal ini disebabkan pada terasi grade 1 diproduksi dari rebon tambak dan proses fermentasi yang mendukung sehingga diperoleh kualitas terasi yang sangat baik. Hal ini mendukung tumbuhnya isolat BAL yang menghasilkan bakteriosin yang mampu menghambat bakteri Staphylococcus aureus. Karthikeyan dan Santosh (2009) menyatakan model aksi penghambatan dan bakterisidal terhadap sel yang rentan adalah bakteriosin menempel pada reseptor membran sitoplasma berakibat fungsi membran sitoplasma rusak sehingga menyebabkan terjadinya pengeluaran material intraseluler, sel mengalami lisis dan akhirnya bakteri mati.

\section{KESIMPULAN}

Isolat BAL dari terasi grade 1 memiliki zona hambat terbesar $2,27 \pm 0,24 \mathrm{~mm}$ terhadap bakteri E. coli, 2,10 $\pm 0,38 \mathrm{~mm}$ terhadap bakteri Vibrio parahaemolitycus, dan $1,33 \pm 0,03 \mathrm{~mm}$ terhadap bakteri $S$. aureus. Terasi grade 1 
Tabel 2 Skrining bakteriosin sebagai antibakteri

(Table 2 Screening for bacteriocin as antibacterial)

\begin{tabular}{ccccc}
\hline No & $\begin{array}{c}\text { Kualitas udang/Quality of } \\
\text { shrimp paste }\end{array}$ & $\begin{array}{c}\text { E. coli } \\
(\mathrm{mm})\end{array}$ & V.parahaemolitycus $(\mathrm{mm})$ & S. aureus $(\mathrm{mm})$ \\
\hline 1 & Kualitas 1/Grade 1 & $2.27 \pm 0.24^{\mathrm{a}}$ & $2.10 \pm 0,38^{\mathrm{a}}$ & $1.33 \pm 0.02^{\mathrm{a}}$ \\
2 & Kualitas 2/Grade 2 & $1.73 \pm 0.59^{\mathrm{b}}$ & $1.38 \pm 0.25^{\mathrm{b}}$ & $1.07 \pm 0.03^{\mathrm{b}}$ \\
3 & Kualitas 3/Grade 3 & $1.31 \pm 0.01^{\mathrm{c}}$ & $1.31 \pm 0.19^{\mathrm{c}}$ & $1.22 \pm 001^{\mathrm{c}}$ \\
\hline
\end{tabular}
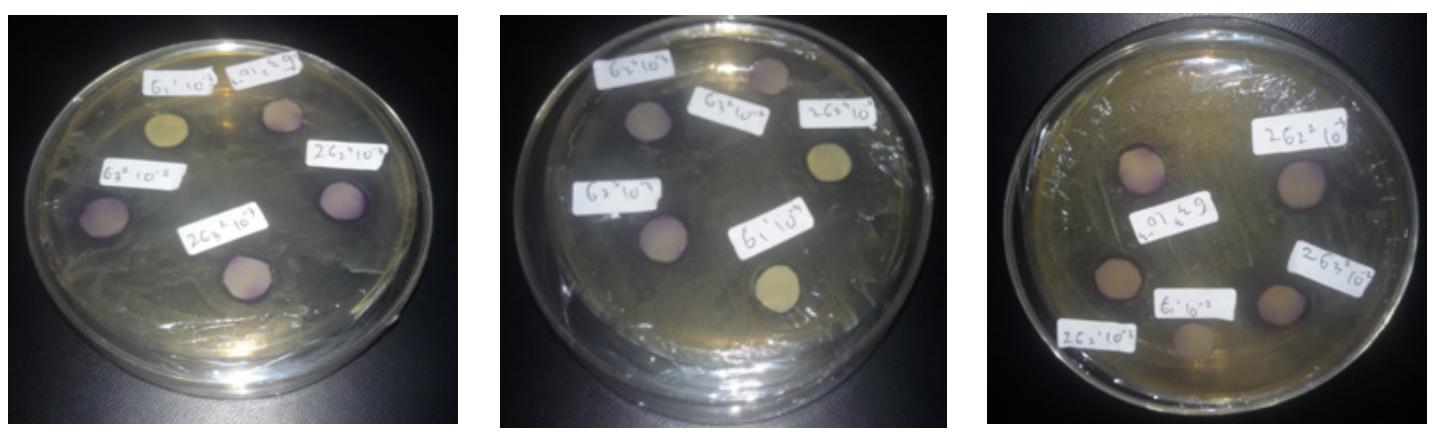

Gambar 1 Zona hambat terhadap bakteri E. coli (A), V. Parahaemolitycus (B), S. Aureus (C)

(Figure 1 Inhibitory zone against E. coli (A), V. Parahaemolitycus (B), S. Aureus (C))

memiliki kualitas yang cukup baik yaitu kandungan asam glutamat paling tinggi $(40,50 \%)$, kadar protein $(42,78 \%)$, lemak (5,33\%), air (27,85\%), abu (29,48\%), dan karbohidrat (14,78\%).

Standarisasi terasi diperlukan sehingga pada produk terasi tersebut dapat menjadi produk andalan dan bermanfaat serta diperlukan proses pemurnian untuk menghasilkan kualitas bakteriosin lebih bagus. Penelitian ini dapat diterapkan untuk produk fermentasi hasil perikanan lainnya.

\section{DAFTAR PUSTAKA}

[AOAC] Association of - Official Analytical Chemist. 2005. Official Methods of Analysis of The Association of Official Analytical Chemist. Arlington, Virginia (USA): Association of Official Analytical Chemists Inc.

[AOAC] Association of Official Analytical Chemist. 2007. Official Methods of Analysis of The Association of Official Analytical Chemist. Arlington, Virginia (USA): Association of Official Analytical
Chemists Inc.

Andriyani E A, Yuliati K, Supriadi A. 2012. Efisiensi dan identifikasi Loss pada Proses pengolahan terasi udang rebon (Acetes sp.) di Desa Belo Laut Kecamatan Muntok Bangka Belitung. Fishtech. 1: 2640.

Arena M P, Silvain A, Normanno G, Grieco F, Drider D, Spano G, Fiocco D. 2016. Use of Lactobacillus plantarum strains as bio-control strategy against food-borne pathogenic microorganisms. Frontiers in Microbiology. 7: 464-474.

[BSN] Badan Standardisasi Nasional. 2009. Standar Nasional Indonesia No. 01- 27162009. Jakarta (ID): Badan Standardisasi Nasional.

Cai Y. 1999. Identification and characterization of Enterococcus species isolated from forage crops and their influence on silage fermentation. Journal Dairy Science. (64): 2466-2471.

Desniar, Rusmana I, Suwanto A, Mubarik N R. 2011. Penapisan bakteriosin dari bakteri asam laktat asal bekasam. Jurnal 
Pengolahan Hasil Perikanan Indonesia 14(2): 124-133.

Drider D, Fimland G, Hechard, Y, Mmmullen, Prevost H . 2006. The continuing Story of Class IIa Bacteriosins. Microbiology and molecilar Biology Reviews. 70(2): 562-582.

Galvez, A, Abriouel, H, Lopez, L R. 2007. Bacteriocin-based strategies for food biopreservation. International Journal of Food Microbiology.120: 51-70.

Hajar S, Hamid T H T. 2013. Isolation of lactic acid bacteria strain Staphylococcus piscifermentans from Malaysian traditional fermented shrimp "cincaluk". International Food Research Journal 20 (1): 125-129.

Hajep, Jinap. 2012. Fermented Shrimp Products as Source of Umami in Southeast Asia. Journal Nutrition and Food Science.: 2155-9600.

Haitha, Zaiton H, Norrakiah SS, Huda Faujan. 2017. Assesment of potential probiotic properties lactid acid bacteria from shrimp paste or balacan. International Journal of Advances in Science Engineering and Technology. 5(11).

Karthikeyan V, Santosh S W. 2009. Isolation and partial characterization of bacteriocin produced from Lactobacillus plantarum. African Journal of Microbiology Research. $3: 233-239$.

Kusmawarti A, Rachman F, Haryati S. 2014. Eksplorasi bakteriosin dari bakteri asam laktat asal rusip bangka dan kalimantan. Jurnal pascapanen dan bioteknologi kelautan dan perikanan (9): 29-40.

Noopur M S, Sucheta N P, Aglave B A. 2010. Extraction of bacteriocin and study of its antagonistic assay. International Journal of Biotechnology and Biochemistry. 6: 865870.

Noordiana N, Fatimah A B, Mun, A S. 2013. Antibacterial agents produced by lactic acid bacteria isolated from Threadfin Salmon and Grass Shrimp. International Food Research Journal. 20(1): 117-124.

Nurhajati J, Atira, Aryantha I N P, Kadek I D G. 2012. The curative action of Lactobacillus plantarum FNCC 226 to Saprolegnia parasitica A3 on catfish (Pangasius hypophthalamus Sauvage). International
Food Research Journal. 19(4): 1723-1727.

Oshea E F, Cotter P D, Stanton C, Ross R P, Hill C. 2012. Production of bioactive substances by intestinal bacteria as abasis for explaining probiotic mechanisms: Bacteriocins and conjugated linoleic acid. International Journal of Food Microbiology. 152: 189-205.

Peng C, Borges S, 1Magalhães, R, Carvalheira A, Ferreira V, Casquete R, Teixeira. 2017. Characterization of anti listerial bacteriocin produced by lactic acid bacteria isolated from traditional fermented foods from Kamboja. International Food Research Journal. 24(1): 386-393.

Romawati M D, Ma'ruf W P, dan Romadhon. 2014. Pengaruh kadar garam terhadap kandungan histamin, vitamin B12 dan nitrogen bebas terasi ikan teri (Stolephorus sp.). Jurnal Pengolahan dan Bioteknologi Hasil Perikanan. 3(1): 80-88.

Sharif R, Ghazali A, A R Rajab, N F Haron H, Osman F. 2008. Toxicological evaluation of some Malaysian locally proceed raw food products. Food and Chemical Toxicology. 46: 368-374.

Thapa N. 2002. Studies on microbial diversity associated with some fish products of the eastern himalayas. [thesis]. India (IN): North Bengal University, Darjeeling.

Yu J, Gao W, Qing M. 2012. Identification and characterization of lactid acid bacteria isolated from traditional pickles in sichuan china. The Journal of General and Applied Microbiology. 58 (3): 163-172. 